\title{
The Effects of Social Media Marketing on Church Growth: A Case of PCEA Evergreen Church, Nairobi Kenya
}

\author{
Peris Muchuki ${ }^{1}$, Peter Kiriri ${ }^{2}$ \\ ${ }^{1}$ Chandaria School of Business, United States International University - Africa, Kenya \\ ${ }^{2}$ Corresponding Author, Chandaria School of Business, United States International University - Africa, Kenya
}

\begin{abstract}
E-commerce is an essential strategy for contemporary organizations since a significant percentage of the population relies on online information. Social media is a popular unconventional e-commerce approach used by organizations to achieve predictable goals using very low budgets. Churches, like every other organization, take advantage of the benefits presented by social media to fuel growth through innovation, relationships. The researcher narrows down the investigation to Nairobi and focuses on the PCEA Evergreen Church along Kiambu Road. The parish provided 88 respondents obtained through multistage sampling method. The researcher used a cross-sectional, descriptive approach. Socio-demographics, brand visibility, and customer satisfaction are the independent variables used to correlate the link between social media and church growth. IBM SPSS ${ }^{\circledR}$ version 24 and Microsoft Excel were the analysis instruments whereby each respondent had a church growth index that was linked to their feedback. Findings indicate that social media marketing influences church growth since it revolutionizes communication, it provides a platform for the church members to speak out, it promotes a learning environment, and enhances the collaboration of members and fastens the achievement of church objectives. Conclusively, the adoption of social media marketing is an indisputable path towards the growth of church and recommendations exploit all elements that may trigger growth and help keep the young people in church.
\end{abstract}

Keywords- Social Media, Marketing, Church Growth, Technology, Communication

DOI: $10.7176 / \mathrm{EJBM} / 11-6-15$

\section{INTRODUCTION}

Four forces have greatly influenced the current and will continue to influence future trends in marketing because they have permeated all areas of marketing, including management, research, and theory. The forces include; globalization, technology, personalization, and integration. Amongst all these forces, technology has the tremendous power to enhance people's lives, promote economic growth, and establish opportunities for individuals, businesses, and countries worldwide [1]. Technology has had a colossal change in the last two decades and has affected every aspect of marketing. In view of this, marketing and technology are merging to make ecommerce an essential part of the marketing strategy. Additionally, most individuals virtually live on the internet. For convenience purposes, marketers must have practical understanding about technology in order to target, attract, and maintain these online consumers.

Personalization is a marketing trend that forces organizations to focus on the individual rather than the mass. Firms should exhibit a strong focus on enhancing the client's experience while driving growth and ensuring client loyalty. To achieve this kind of balance, organizations require marketing executives to personalize their branding and advertising techniques. Experiential Marketing establishes a chance for clients and prospects to have an encounter with the organization's brand, whether in a virtual setting or in person. The integration of old marketing methods and new innovative ones such as social media marketing presents an opportunity for market competitiveness. It would be difficult to deny the fact that evolution of media since print to radio followed by television and currently online media has repeatedly influenced mass opinions and perceptions. However, the advent of social media sites has taken this very concept to higher levels than could be imagined in shaping the opinions, perception, and actions of people all over the world [3].

Like any other organization, churches need to take advantage of the social media class to remain relevant in the modern day society. More so, churches need to create value for their followers to retain them and grow. This has been made possible by the advent of the internet and social channels that totally changed the way of doing things. Social Media includes a range of tools and services that enable direct user interaction on computer-mediated environments [4]. With its viral nature to connect millions of people in an instant and user-driven environment, it enables total strangers to bond over common beliefs, desires, or interests and create common winners and losers [3].

Social media has its challenges because it does not operate in a free environment and it encounters some barriers that include; poor infrastructure low literacy levels and culture apprehensions to new technology that hinders its use (Kamp, 2016; Lampe et al., 2011). Profit interest that makes it unreachable for use or the fact of overuse because it has no controls, generation gap, where the young embrace it wholly while the old have reservations, regulations to its use and the fact that it can be misused or abused making it offensive. Moreover, the 
sites may not meet the needs of stakeholders who just choose to make do with what they have for lack of choice due to lack of consultation during design stage and hardware being too difficult to use[4].

Though various studies have been done in the field of social media marketing in Kenya, very little or no research has investigated the effect of Social Media Marketing on churches in Kenya. In view of this gap, the study was chosen to investigate how churches are making use of social media for ministerial activities, keeping up with the latest trends to improve the brand's image with a key focus on PCEA Evergreen church.

The result of the study sought to fulfill the mandate for which they exist; which was to get the gospel to the whole world. The purpose of this study is to investigate the effect of Social Media Marketing on church growth using the case of PCEA Evergreen parish in Nairobi. The target population of study includes the church members and parish officials who use the cyberspace and social media to access church information. The results, however, are applicable to all PCEA churches and other denominations. The data was collected at PCEA Evergreen Church along Kiambu road between April 15th and April 22nd, 2017. Data analysis was completed on 29th of April 2017.

\section{Effects of Social Media Marketing on Church Growth}

\section{LITERATURE REVIEW}

The current century has seen a great evolution in the way firms market their products and services. Companies are currently undergoing some unexpected activities and the development of the cyberspace as a communication medium is undoubtedly nearly one of the most dominant factors. The Internet has brought about several modern aspects, it has made clients more reachable, it has come up with a modern set of communication tools that make the process of exchanging knowledge and ideas much conveniently, and it has pushed companies to rethink how they are communicating with their clients [5]. The use of ICT in the church has been noted in the last two decades in contemporary church communications for growth. Contemporary church communications for growth is taking phenomenally great strides. However, adoption levels vary across countries, church groups, church budgets, and with the increasing threat to mass gathering by insurgencies, the rate of adoption will further increase.

\section{Social Media Defined}

Social media is a word that describes a range of web-based platforms applications and technologies that people use interact socially interact online [6]. They include; Facebook, Twitter, YouTube, Wikis, Wikipedia's, Blogs, social bookmarking, Instagram, Google among others. Social Media use is invariably linked to the internet. Kenya's social media accelerated in the last five years with 18 million people on facebook groups, twitter, and the rest [7]. It is noted that social media platforms have played various roles in the country, the first being in 2013 during the general elections. The other was in the time of adversity when Westgate mall was attacked and the country was unified in the course [7]. Social media is projected to impact interactions at all levels like never before in view of its explosive growth particularly in the coming general elections in this year 2017 [7]. This is the level at which the social media is in the country to be harnessed by the churches as part of their growth strategy which necessitated this study.

A survey in Africa on the use of ICT in churches revealed that all Christian churches were using ICT to support their faith practices with notable use in the Protestant churches as well as tremendous adoption in the mega-churches which was a replica of churches in the USA and world [8]. Online evangelism is surfacing as a new methodology to traditional evangelism where members have had to find a church at specific location for fellowship [9]. However, competition from alternative forms of religious practices, and other competing churches working on converting members and the availability of more information, where people can seek and find more about competitive groups before commitment [9], leaves the churches no option but to embrace new forms of work methods to remain competitive. Social media, therefore, comes as an answer to this new way of doing business in that it has the capacity to meet the requirements for the church.

\section{Church Growth}

Church growth is determined by the increase in numbers. One would then assume that growth in numbers signifies growth in revenue, in faith as well as geographical scope [10]. Without membership, there is no church because a church is simply the collection of all individual Christians [10]. However, congregations' growth goal is to reach more people with their gospel message, or aim to remain viable. For church growth to happen the children and the youth must be retained in the church and the decline is happening because half of the children of the churchgoers are not in church [11]. Growth is also a product of good leadership and it requires a charismatic leader who has the vision to inspire the congregation with a good vision. To guarantee growth, church leaders should show the ability to engage with outsiders and newcomers and exhibit a vision for growth. The other factors for church growth are that the church must be inclusive and involve the community where the church is based by aiming to be a community church, be a welcoming church and follow up on visitors, have a program to nature and the new and existing[12]. 


\section{Social Media and Church Membership}

Church membership is ascertained through the retention of the children and the youth in the church. Once retained, they must be engaged in church activities like retreats, conferences, camps, or church school [12]. Social media can be used to promote these programs by creating involving platforms that are personalized and attractive to the potential. This activity will create the interest to stay in church which would lead to church growth in membership. However, care should be taken to avoid overuse and abuse of the social media by the church having a policy in place to govern the same. Moreover, social media is distinguished by content created for the user which has been found to be very effective than traditional marketing communications in terms of influencing attitudes and behavior of other users [13]. In view of this, social media can be used as a tool for training, posting guidelines, soul winning, creating prayer bands, post sermons to be read at the members' convenience, create support groups like single parents, ladies, widows, or senior youth to create a sense of belonging. While there are still many churches thinking about whether they should use social media or not, there are already very many people utilizing these platforms online. When a church decides not to embrace social media especially Facebook, they stand to lose a big opportunity to minister to both new and old souls [9].

\section{Social Media and Faith}

On the issue of growth in faith, the advent of the internet has made religion to maintain a very strong online presence to which people connect. Social media is for relationships and when people connect, these relationships are strengthened and it exposes the people to the impact of their network of friends [14]. Members usually share their major life experiences or stories about their spiritual journey online, making social media an instrumental influencer in transforming people. Blogs avail information to people for Christians and enable the members to interact with great thinkers and get sermons from the pastors. YouTube, on the other hand, is a source of spiritual teaching by pastors and professors and it offers lots of resources on Christianity that enhances one's faith [15].In addition to that social media can be used to pastor a church or churches and can be used for viral evangelism where a message can be passed to millions of people in an instant; moreover, social media can be used to point out God in culture. Social media is, therefore, a social exchange tool that churches could use to increase faith in the membership and church. What needs to be done is to guide against risk by instituting a policy for its use [6].

\section{Social Media and Revenues}

A church's survival depends on numbers and faster-growing churches have more members who devote themselves beyond time and worship. The authors posit that the higher the percentage of attendance to the services, the faster the growth of the church; which signified that members contributed more in revenue. During the research, however, the authors established the above fact to be weak; however, it was noted that the members instead contributed in kind in terms of the membership talents [16]. This means that there are other sources of revenue for the churches besides membership contributions and they include; annual or sustained gifts, major gifts, planned gifts, foundation grants, cause-related marketing, corporate giving programs, earned income activities, unrelated business income, in-kind donations, supporting organizations, benefit events, state and local municipalities, churches and denominations, federated funds and online donations [17].

\section{Social Media and Geographical Scope}

Social media has now become an increasingly popular component of everyday life in the current global society and has enabled people across the world to communicate, exchange messages, share knowledge, and interact with each other; distance separating them notwithstanding. This has led to understanding through interaction creating a new cultural environment that overlooks traditions, beliefs, and norms thus surmounting differences in culture [18].

\section{Social Media and Organizational Growth}

Religious institutions, particularly churches are confronted with dilemma when it comes to marketing of their services because marketing has been seen as a preserve for the secular business world and monetary value [19]. The authors, however, believe that marketing a tool that enables the churches to fulfill their commission of spreading the gospel and winning souls and is the answer to the dilemma of getting lost the attention of the people and it has proved so as revealed by various studies [19]. Marketing as a tool is applicable to the church and can be used to accomplish its objectives that include; improving church image, increasing attendance as well as membership loyalty and fundraising for church projects, segment target groups, like volunteers and donors when it comes to fundraising activities or selling certain church products that do not involve certain values and dogma of the church [19]. Churches have no choice but to advertise to remain relevant for modern-day individuals and must create value for their consumers. 


\section{RESEARCH METHODOLOGY}

This study used a cross-sectional descriptive study design. The study population comprised of church members, non-members attending services and parish staff at PCEA Evergreen Church, in Nairobi Kenya. Approximately 875 individuals met these criteria and attended services at the church every Sunday.

Table 1: Population Distribution

\begin{tabular}{lcc}
\hline Respondent Category & Frequency (n) & Percent (\%) \\
\hline Church Members & 656 & 75.0 \\
Non-Members & 146 & 16.7 \\
Parish Staff & 73 & 8.3 \\
Total & $\mathbf{8 7 5}$ & $\mathbf{1 0 0 . 0}$ \\
\hline
\end{tabular}

Multistage sampling was used to recruit respondents for the study. Respondent category formed the strata for the study sample. Once the numbers of people in each stratum are known, convenience sampling would be used to recruit that number. Attendees of the church services were all invited to participate as per the required numbers in each stratum until the minimum sample size was reached. The sample size for this study was estimated based on the $10 \%$ condition, which is a statistical rule stating that "The sample size, n, must be no larger than $10 \%$ of the population" (Berry and Lindgren, 1995).

Therefore, given a population of 875 church members:

$$
n \leq \frac{10 \times N}{100}
$$

Where,

$$
\begin{aligned}
& \mathrm{n}=\text { desired sample size } \\
& \mathrm{N}=\text { Population size }
\end{aligned}
$$

Therefore,

$$
n \leq \frac{10 \times 875}{100}=87.5
$$

As such, the maximum sample size for this study was 88 respondents. The distribution of the study sample can be seen in Table 2 below.

Table 2: Sample Size Distribution

\begin{tabular}{lcc}
\hline Respondent Category & Frequency (n) & Percent \\
\hline Church Members & 66 & 75.0 \\
Non-Members & 15 & 17.0 \\
Parish Staff & 7 & 8.0 \\
Total & $\mathbf{8 8}$ & $\mathbf{1 0 0 . 0}$ \\
\hline
\end{tabular}

Since this study was quantitative in nature, Self-administered questionnaire was provided to the respondents after prior notification. The questionnaire was administered in English language and comprised four major sections: socio-demographic data, church growth, brand visibility and customer/member satisfaction factors. Except for the socio-demographic questions, the other sections of the questionnaire comprised Likert scales with five possible answers ranging from "Strongly Disagree, Disagree, Unsure, Agree and Strongly Agree". These Likert scales were used to generate additive indices for the data analysis. The questionnaires were issued to the respondents at the entrance as they came in for the service and during offering time then they were collected at the end of the service. To improve the response rate, this process was explained the previous week and was also included in the church bulletin requesting the members to participate as part of the church development initiative. This was in addition to an announcement from the pulpit during announcement highlight time, to sensitize the members on the importance of completing the questionnaire. This helped increase response rate from the membership. 
A pre-test of the questionnaire was carried to ensure the validity of the research instrument. The views of selective respondents on matters of clarity, relevance of questions, ease of understanding and experiences when filling the research instruments were addressed in the final research instrument. Additionally, Cronbach's alpha $(\alpha)$ was used to assess the reliability of the questionnaire. Prior to data collection, potential respondents had the study explained to them and they were given opportunity to ask questions. After they gave informed consent to participate in the study, each respondent recruited for the study was assigned a serialized questionnaire, and given at least 5-10 minutes to complete the survey. This was to ensure minimal interference with the church services on the day of data collection. Additionally, to ensure that the response rate was high, the researcher was on hand to address any questions and provide clarifications as needed to the study respondents. Further, the data collection process was announced in the church a week prior to collection and reminders were sent to members to ensure a high response rate for the data collection.

Data analysis was carried out using IBM SPSS ${ }^{\circledR}$ version 24 and Microsoft Excel. In the case of discrete variables, frequency tables with single or multiple cross-classification criteria were provided to give a good description of the variables. Tables and Figures were also provided to display data patterns. Each member had a church growth index generated based on their responses to the questionnaire. At the level of bi-variate analysis, Pearson's product-moment correlation coefficient (r) was used to establish the effect of social media marketing on church growth. The effect of the other independent variables on church growth was also assessed using Pearson's correlation. Sampling and measurement errors were provided. To adjust for confounding, all independent variables that significantly correlated with the dependent variable at bi-variate analysis were considered together using multiple linear regression, all tests were two-sided. A value of $\mathrm{p}<0.05$ was considered statistically significant.

\section{General Information and Demographics}

\section{RESULTS AND FINDINGS}

The researcher handed out 93 questionnaires. A total of 88 questionnaires were returned, resulting in a response rate of $94.6 \%$ (Table 3). The respondents were aged between below 20 and above 51 years. Those aged above 51 years formed the largest group of respondents (24.1\%), while those aged less than 20 years were the least populous. Males accounted for almost two-thirds of the sample $(60.9 \%)$ while the females were less, accounting for $39.1 \%$. The majority (59.1\%) of the respondents were married, followed by those who were single with $37.1 \%$. Those that were divorced involved one person accounting for $1.1 \%$ of the sample while two people $(2.3 \%)$ indicated that they were widowed. The respondents' education ranged from a minimum of primary to postgraduate with postgraduate being more with $39.8 \%$ followed by undergraduate at $23.9 \%$ and primary level the list with $3.4 \%$ of the study sample. Out of the total respondents, $80.7 \%$ were church members, $3.4 \%$ were employees of the church, while the remaining $15.9 \%$ were non-church members.

Table 3: Response Rate by Category

\begin{tabular}{lccc}
\hline Respondent Category & $\begin{array}{c}\text { Expected } \\
\mathrm{n}(\%)\end{array}$ & $\begin{array}{c}\text { Handed Out } \\
\mathrm{n}(\%)\end{array}$ & $\begin{array}{c}\text { Received } \\
\mathrm{n}(\%)\end{array}$ \\
\hline Church Members & $66(75.0)$ & $73(78.5)$ & $71(80.7)$ \\
Non-Members & $15(17.0)$ & $15(16.1)$ & $14(15.9)$ \\
Parish Staff & $7(8.0)$ & $5(5.4)$ & $3(3.4)$ \\
Total & $88(100.0)$ & $93(100.0)$ & $88(100.0)$ \\
\hline
\end{tabular}

\section{Use of Social Media}

Face book was the most accessible social media platform for respondents at PCEA Evergreen church (TABLE 3). $(94.0 \%)$ of the members of PCEA Evergreen Church access social media via their phones and the remaining $6 \%$ access it through their computers. Another $17.9 \%$ use tablets. Two-thirds $(66.3 \%)$ of members reported that they had interacted with their fellow church members through Social Media, whereby $90.7 \%$ of interacted daily and the rest $(9.3 \%)$ interacted on a weekly basis (Figure 1$)$. 
Table 3: Most Accessible Social Media Platform

\begin{tabular}{lrr} 
Social Media Platform & Frequency (n) & Percent (\%) \\
\hline Facebook & 55 & $67.1 \%$ \\
Twitter & 12 & $14.6 \%$ \\
LinkedIn & 14 & $17.1 \%$ \\
Instagram & 14 & $17.1 \%$ \\
Snapchat & 4 & $4.9 \%$ \\
WhatsApp & 8 & $9.8 \%$ \\
\hline
\end{tabular}

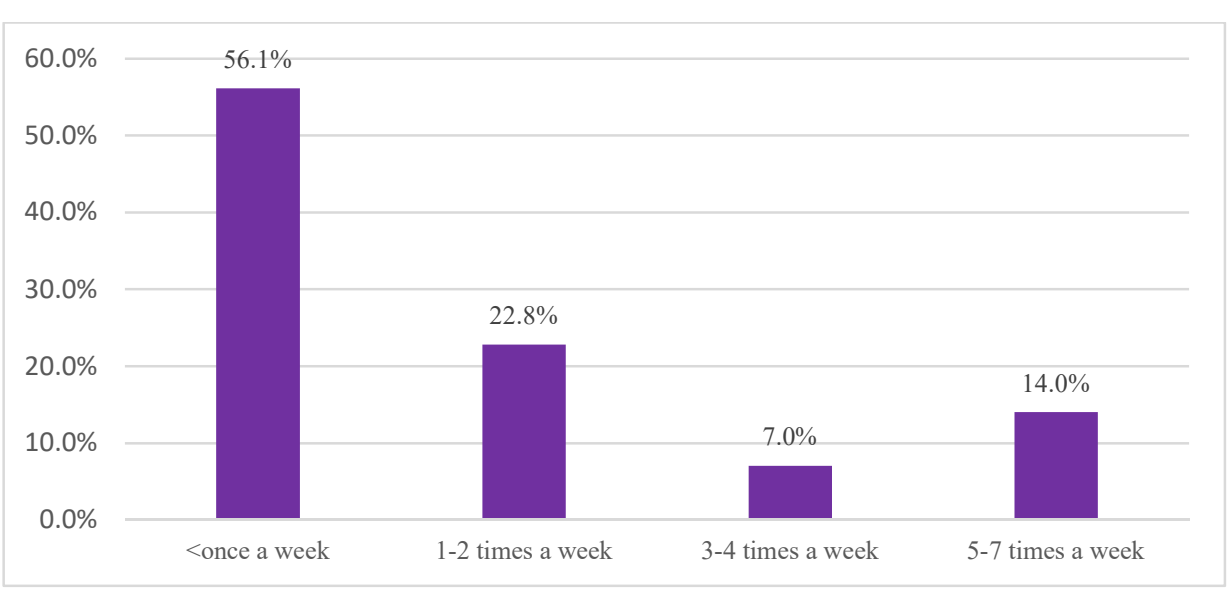

Figure 1: Frequency of Interaction on Social Media

\subsection{Social Media Marketing and Church Growth}

Respondents opinions on church growth at PCEA Evergreen were that the church had on average, registered some growth and while some aspects registered significant growth and improvement, other areas seem to have lagged despite adoption and use of internet and social media for a long time and that the rate of internet usage was still low. However, the membership believed that social media and internet had the capacity to increase church membership as well as spiritual growth since social media seemed to be an effective tool for evangelism.

Table 4: Church Growth Variables

\begin{tabular}{|c|c|c|c|}
\hline Church Growth Variables & $\begin{array}{l}\text { Disagree } \\
\mathrm{n}(\%)\end{array}$ & $\begin{array}{l}\text { Unsure } \\
\mathrm{n}(\%)\end{array}$ & $\begin{array}{l}\text { Agree } \\
\mathrm{n}(\%)\end{array}$ \\
\hline The church has long used social media & $26(31.3)$ & $29(34.9)$ & $28(33.7)$ \\
\hline Internet and social media use by the church is low & $26(31.7)$ & $18(22.0)$ & $38(46.3)$ \\
\hline I think this church has a strong online presence & $26(32.9)$ & $29(36.7)$ & $24(30.4)$ \\
\hline The church improved in after adopting internet use & $17(21.0)$ & $22(27.2)$ & $42(51.9)$ \\
\hline Church members can be easily reached on Social Media platforms & $11(13.4)$ & $10(12.2)$ & $61(74.4)$ \\
\hline Church attendance grew with use of social media & $23(28.4)$ & $36(44.4)$ & $22(27.2)$ \\
\hline Social media can help to increase church membership & $9(11.0)$ & $15(18.3)$ & $58(70.7)$ \\
\hline $\begin{array}{l}\text { Social media has helped improved relationships with fellow } \\
\text { members }\end{array}$ & $15(18.5)$ & $15(18.5)$ & $51(63.0)$ \\
\hline I prefer to be ministered to from Social Media platforms & $51(62.2)$ & $11(13.4)$ & $20(24.4)$ \\
\hline $\begin{array}{l}\text { Social media evangelism is just as effective as face to face } \\
\text { evangelism }\end{array}$ & $32(40.0)$ & $22(27.5)$ & $26(32.5)$ \\
\hline $\begin{array}{l}\text { Social media marketing promotes spiritual growth among } \\
\text { Christians }\end{array}$ & $11(13.6)$ & $19(23.5)$ & $51(63.0)$ \\
\hline Social media evangelism is not effective & $41(52.6)$ & $18(23.1)$ & $19(24.4)$ \\
\hline
\end{tabular}


With reference to Table 4, the church adopted the use of social media and internet long ago as only $31.3 \%$ agreed with $34.9 \%$ being unsure and only $33.7 \%$ agreeing to a short period of adoption and use. However, the church seemed not to have fully utilized internet and social media (46.3\%) with $22.0 \%$ being in agreeing but $31.7 \%$ were unsure. $51 \%$ of the respondents agreed that the church generally experienced improvement due to social media while $17 \%$ disagreed and $22 \%$ not being sure. The church had also an online presence after albeit $30.4 \%$ which appeared weak as $36.7 \%$ were not sure it existed and $32.7 \%$ totally disagreed.

Regarding retention of church members, the growth impact was noted in relation to the reach the church had to its members via social media where the majority, $(74.4 \%)$ reported that church members were easily reached on various social media platforms with only $13.4 \%$ disagreeing. This proved to be a good retention strategy. The respondents also agreed that social media helped improve relationships with fellow members $(63.0 \%)$. However, church attendance did not grow much $(27.2 \%)$ while $44.4 \%$ were unsure of the growth and $28.4 \%$ did not experience increase in church attendance (Table 4).

On matters of faith, members believed that social media could promote spiritual growth $(63.0 \%)$, they felt that social media was effective as $52.6 \%$ disagreed that it was ineffective and only $19 \%$ believed it was ineffective. However, the belief did not tally with the members' preference in that $24.4 \%$ of the respondents preferred to be ministered to from social media platforms while $62.2 \%$ did not like it and $13.4 \%$ were not sure of the preference. This could be seen in the response on whether social media was as good as face to face evangelism and only $32.5 \%$ felt that it was while $40.0 \%$ disagreed and $27.5 \%$ were even not sure (Table 4 ).

\section{Regression Analysis}

To adjust for confounding, all the church growth variables that were statistically significantly correlated with social media marketing were considered together using multiple linear regressions. The results of the regression analysis indicated that the variables explained $71.5 \%$ of the change in the dependent variable ( $\mathrm{R}$ squared change $=0.779, \mathrm{~F}$ change $(12,41)=12.06, \mathrm{p}<0.001)$.

The results of the regression analysis show that social media marketing enhanced church growth at PCEA Evergreen in 3 main ways. First, it led members to prefer social media ministry over traditional ministry $(\beta=0.279$, $\mathrm{p}=0.002)$. Secondly, social media marketing has helped the church to fundraise online $(\beta=0.247, p=0.017)$. Lastly, social media marketing has helped to increase membership numbers $(\beta=0.202, p=0.046)$.It also reveals that social media marketing has led to availability of information to the membership due to online presence $(\beta=0.246$, $p=<.001)$, enhance brand recognition $(\beta=0.161, p=0.043)$, enhanced church communication $(\beta=0.168, p=0.049)$ as well as member retention $(\beta=0.207, \mathrm{p}=0.003)$.

\section{DISCUSSIONS, CONCLUSIONS, AND RECOMMENDATIONS}

Social media marketing was found to impact church growth in various aspects that included; improvement of church image, church attendance, church membership loyalty, church revenues through fundraising activities, and church communication as well as brand visibility that covers brand awareness, brand equity, and brand loyalty. These findings echoed the study of commercial banks, which confirmed that use of social media increased in customer base resulting in improved revenues (Mutero, 2014). Therefore, social media may not affect church revenues directly or immediately but in the long analysis, the increase of members may affect the church's revenue. This study also confirms that social media enables faster and consistent communication as well as making purposeful encounters and bringing people together (Robinson, 2014). Social media is the 21 st town square where significant conversations take place and recommend that every church must be on it for gospel impact and influence on the community (Stetzer, 2015). That is why churches with significant online presence grow (Hadaway, 2011).Social media provides the social capital to enhance a church's organizational image. It has the propensity to increase reputation and anticipated reciprocity that affects attitudes and motives that may increase church attendance. Besides added benefits of improved image and membership loyalty, also increases church attendance (Angheluta, Strambu-Dima, and Zaharia, 2010). Due to the growth opportunities presented by social media, most Protestant churches have opted to adopt the applications to sustain, reinforce, and grow their churches.

Church growth encompasses aspects of church image, church attendance, church membership loyalty, church revenues, communication, and brand visibility. The study established that social media impacts these aspects directly and immediately as noted from the study because these are the ones that registered significant growth after adoption of social media marketing at PCEA Evergreen church [20]. It is important to note that church revenues improved through fundraising using social media, but from the responses were given it was noted there could have been other methods used that accounted for the increase apart from social media us alone. Communication was improved tremendously using social media and it formed to be the basis for forging member relationships and later caused impact on other aspects of church growth. It is imperative therefore that churches seek to leverage on the social media platforms particularly Face book, to sustain, reinforce and grow.

To improve on this aspect, churches need to have a clear growth strategy to exploit all elements that spur growth and enable them to retain the youth in the church noting that use of social media failed. It would be of great 
importance to establish factors that lead to youth joining and staying on in church. On the other hand, to improve on the study, there is need to consider other areas of church growth besides social media particularly on member retention or factors for leaving the church to come up with retention strategies.

\section{REFERENCES}

[1] R. E. Goldsmith, "Current and future trends in marketing and their implications for the discipline," Journal of Marketing Theory and Practice, 12(2), 2004, 10-17.

[2] J. M. Arnold, "Top Ten Marketing Trends Every Credit Union Should Know," 2014. [Online]. Available: http://www.cornerstoneleague.coop/repository/Top+10+Marketing+Trends+Every+CU+Should+Know.pdf. [Accessed 15 June 2017].

[3] M. Kamp, "Reality Check. Assessing the Impact of Social Media on Political Communication and Civic Engagement in Uganda. Kampala, Uganda," Konrad-Adenauer-Stiftung, 2016. [Online]. Available: http://www.kas.de/wf/doc/kas_43976-1522-2-30.pdf?160125084552. [Accessed 01 November 2017].

[4] C. Lampe, R. LaRose, C. Steinfield and K. DeMaagd, "Inherent barriers to the use of social media for public policy informatics," The Innovation Journal: The Public Sector Innovation Journal, 16(1), 2011, 117.

[5] A. Jaokar, B. Jacobs, A. Moore and J. Ahvenainen, Social media marketing: How data analytics helps to monetize the user base in telecoms, social networks, media and advertising in a converged ecosystem London, UK: Futuretext, 2009.

[6] R. Cruz, "Social media to go. A compilation of best practices, policies and how -to guides," The University of Geogia, August 2012. [Online]. Available: http://archwaypartnership.uga.edu/wpcontent/uploads/2012/08/Social-Media-Guide_Rosanna-Cruz_2012_FINAL_reduced.pdf. [Accessed 10 November 2017].

[7] M. W. Kaigwa, " Kenya at 50: how social media has increased the pace of change," The Guardian, 13 December 2013. [Online]. Available: https://www.theguardian.com/global-development-professionalsnetwork/2013/dec/13/kenya-social-media-mark-kaigwa. [Accessed 8 June 2017].

[8] S. P. Wyche, "Church share: Investigating technology use and adoption among culturally different religious groups," Georgia Institute of Technology, 1 October 2008. [Online]. Available: http://www.academia.edu/download/30843486/10.1.1.169.8799.pdf. [Accessed 12 July 2017].

[9] A. A. Hvass, "The online marketing of religion: Analyzing social media use by online Christian evangelists," University of Agder, Kristiansand and Grimstad, Norway, 2011. [Online]. Available: https://brage.bibsys.no/xmlui/handle/11.

[10] K. Badmos, "Effect of social media on the church in world mission evangelical ministry," Ilesa Nigeria. Lagos, Nigeria, 2014. [Online]. Available: http://www.academia.edu/12388901/Effect_of_social_media_on_the_church. [Accessed 28 July 2017].

[11] D. Voas and L. Watt, "The church growth research programme report on strands 1 and 2," Church Growth Research Programme, 2014. [Online]. Available: Retrieved from http://www.churchgrowthresearch.org.uk/UserFiles/File/Voas_report_technical_version.pdf. [Accessed 2 August 2017].

[12] Church Commissioners of England, "From anecdote to evidence. Findings from the church growth research programme," England: The University of Essex, 2014. [Online]. Available: http://www.churchgrowthresearch.org.uk/UserFiles/File/Reports/Fro. [Accessed 5 August 2017].

[13] F. Parveen, N. I. Jaafar and S. Ainin, "Social media usage and organizational performance: Reflections of Malaysian social media managers," Telematics and Informatics, 32(1), 2015, 67-78.

[14] R. R. Ramsaran-Fowdar and S. Fowdar, "The implications of Facebook marketing for organizations," Contemporary Management Research, vol. 9, no. 1, p. 73, 2013.

[15] P. Pilt, "Social Media: Is it a positive or negative for a person's spiritual journey? An In-depth Analysis," PeterPilt, 25 March 2013. [Online]. Available: https://peterpilt.org/2013/03/25/social-media-is-it-a-positiveor-negative-for-a-persons-spiritu. [Accessed 23 March 2017].

[16] S. Medcalfe and C. Sharp, "A financial analysis of church growth.," Augusta State University, 2011. [Online]. Available: http://www.thearda.com/asrec/archive/papers/Medcalfe\%20\&\%20Sharp\%20\%20A\%20Financial\%20Analysis\%20of\%20Church\%20Growth\%20.pdf. [Accessed 29 March 2017]. 
[17] CCFNRC, "Building multiple revenue sources," CCFNRC, 2009. [Online]. Available: http://strengtheningnonprofits.org/resources/guidebooks/BuildingMultipleRevenueSources.pdf. [Accessed 3 April 2017].

[18] R. Sawyer and G.-M. Chen, "The impact of social media on intercultural adaptation," Intercultur Al Comm Unica Tion S Tudies , vol. 12(2), 2012, 151-169.

[19] A. V. Angheluta, A. Strambu-Dima and R. Zaharia, "Church marketing-concept and utility," Journal for the Study of Religions and Ideologies, 8(22), 2010, 171-197.

[20] PCEA Evergreen Church, "Church Genesis. Retrieved March 23, 2017, from http://pceaevergreen.org/index.php/2014-09-07-08-47-58/church-genesis," PCEA Evergreen Church, 23 March 2017. [Online]. Available: 2017. [Accessed 23 March 2017]. 